\title{
An analysis of the performative nature and power of forensic dialogue in Susanna: A speech act contribution
}

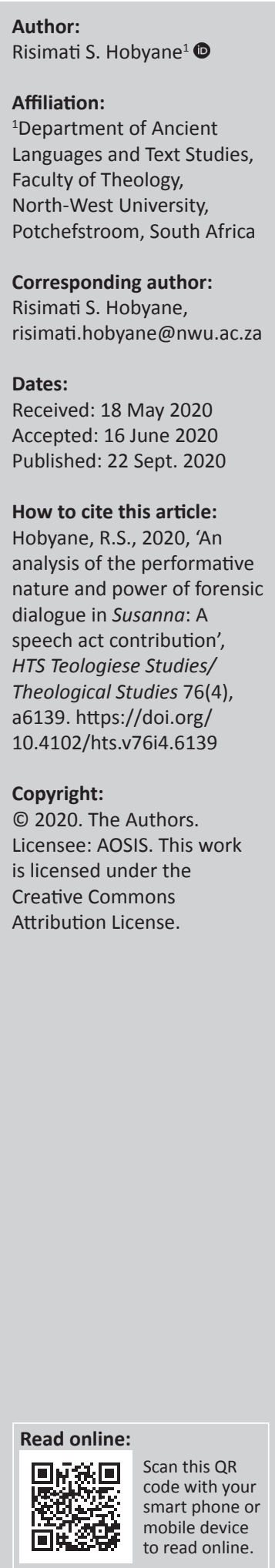

This article investigates the performative nature of forensic dialogue as a literary device in the story of Susanna. Whilst Susanna scholars have brought significant contributions in recent years, this article contends that there has never been a special focus on the performative function of forensic dialogue in Susanna. This aspect should be explored further as it can contribute to how the story can be read, interpreted and applied in contemporary society. The article suggests that the forensic dialogue in Susanna is possibly an intentional literary strategy by the implied author and has a performative function to benefit the implied reader. This means that the implied author uses forensic dialogue to invite participation from the reader. From a speech act interpretive angle, this article attempts to prove this claim by exploring the aforementioned literary device in Susanna and demonstrating its performative nature aimed at the reader.

Contribution: The article's main contribution rests on its unique approach to investigating the performative nature of forensic dynamics in Susanna. This technique of exploring narrative texts does also advance the Susanna scholarship, in that it offers a reader yet another way of reading, interpreting and applying the story to the contemporary society.

Keywords: Judaism; Susanna; Performative; Forensic dialogue; Implied reader; Speech act theory.

\section{Introduction and problem}

Susanna is part of three additions to Daniel found, amongst other places, in the Septuagint (LXX), where it constitutes Chapter 13 of the so-called Greek Daniel (De Bruyn 2015:594). The other two additions are 'The Prayer of Azariah' (part of Daniel 3) and 'Bel and the Dragon' (Daniel 14). This exploration of the performative nature of the forensic dialogue is based on the Theodotion version $^{1}$ from the LXX, edited by Ziegler (1999).

There is general consensus amongst scholars that Susanna can be categorised as a Midrash, written in the Hellenistic period and incorporated into the Greek Daniel somewhere between 100 BCE (De Bruyn 2016:222; see also Collins 1993:426-438) and 80 BCE (Charles 2004:638, 643-644) or even 70 BCE.

Although there have been many insightful contributions ${ }^{2}$ to the study of Susanna, this article focuses on the investigation of the performative ${ }^{3}$ nature of forensic dialogue in Susanna. Whilst doing a survey of Susanna research, in their recent publication, Jordaan and Chang (2018:1) observed that there are four different approaches that have been employed in analysing the story of Susanna:

- historical-critical and historical-grammatical approaches, typically including a comparison of the LXX and Theodotion versions of Susanna

1.There are two versions of the Greek Daniel. Consequently, there are two Susanna accounts. The first account is that of the LXX, which is possibly the older version and therefore often called the Old Greek (OG) version (De Wet 2009:229-231). The second account is the is possibly the older version and therefore often called the Old Greek (OG) version (De Wet 2009:229-231). The second account is the Kanonge (2009:362) points out that despite their significant differences, the two versions present the same plot with the same Kanonge (2009:362) points out that despite their significant differences, the two versions present the same plot with the same
characters. It is beyond the scope of this article to elaborate on the differences between the two versions. The author's belief here is characters. It is beyond the scope of this article to elaborate on the differences between the two versions. The author's belief here is
that the Theodotion choice will not have any influence on the outcome of the analysis of the performative nature of forensic dialogue

2.Coetzer (2009), Jordaan and Branch (2009), De Wet (2009), Kanonge (2010), Nolte and Jordaan (2010), De Bruyn (2015), De Bruyn (2016) and Jordaan and Chang (2018) to mention but a few.

3.In this article, the term 'performative' is understood to mean that the text is formulated and presented in such a way that it invites the reader to participate in it, for example, by persuading or forcing the reader to make a decision when reading it. This entails that the text's primary aim and intention is to achieve something in the life of the reader (Briggs 2001:3; Van der Watt 2010:145). 
- cultural approaches, focusing on issues like the assumed underlying conflict between the Pharisees and Sadducees and the gender prejudice against women

- spiritualising approaches to the Theodotion Susanna, typical in ecclesiastical circles

- unique literary approaches from mainly modern literary points of view, for instance, speech act theory, semiotics and even narrative approaches.

Following Jordaan and Chang's (2018) observations, this article falls into the fourth category, that is, a unique literary approach to the story of Susanna. The current contribution is unique in the sense that none of the studies conducted on Susanna have comprehensively dealt with the performative power and nature of the forensic dialogue in the story. However, this article applauds the work of Coetzer (2009), entitled 'Performing Susanna: Speech acts and other performative elements in Susanna'. Although Coetzer's work used the same methodology, its focus was not on the performative nature of forensics dialogue in the text.

This article observes that Susanna is purposefully formulated and presented as a court trial story (De Bruyn 2015:601; Jordaan 2008a:45-53). The manner in which the story is presented, particularly its forensic dialogue (or that of a court proceeding), is suggestive of the author's possible intentional persuasive strategy. The overarching question that this article addresses is, 'how does the forensic dialogue in Susanna invite the reader to participate in the story?' Furthermore, the article will attempt to answer the following question: to what extent does the trial of Susanna impact the reader's view on issues of social injustice in contemporary society? Therefore, this article analyses the utterances included in this section to answer this question or fill this gap.

\section{The story of Susanna}

Susanna is a short fictional story of 64 verses in the LXX. It is a story about a beautiful and pious Jewish woman who is accused by two Jewish elders of adultery with a young man (Kanonge 2010:7; see also Jordaan 2009:4). Susanna is married to Joachim, an affluent and an influential Jew living in Babylon. The story reveals that Joachim's house and garden serve as a communal gathering place for Jews and a seat of justice (Branch \& Jordaan 2009:393). The observation of Joachim's garden as the seat of justice is indispensable because many of the forensic dialogues that this article intends to analyse are performed in this scene. The story reports that two elders are elected to assume the role of judges within the Jewish community. However, despite their high positions, the two elders are singled out by a prophetic utterance as potential vectors of sexual perversion and exponents of injustice within the community. In fact, each of the elders individually longs for sexual intercourse with Susanna, but without either of them telling the other (v. 10). According to the narrative, each elder informs the other that he intends to go home for lunch. In this way, each elder attempts to have his colleague return home for lunch so that he might secretly remain and have an opportunity to come across Susanna alone in her garden (Kanonge 2010:7). After their failure to have sexual intercourse with her, they accuse Susanna of sexual immorality. The story reaches its climax in a court hearing, where the wicked elders accuse Susanna of sexual immorality and unfairly sentence her to death. The forensic analysis in this article will focus on this trial, from the beginning of the narrative to the end.

\section{Methodology speech act theory: A synopsis}

The analysis of the performative nature of forensic dialogue in Susanna will be done from a speech act interpretive angle. Speech act theory ${ }^{4}$ is a theory of language use and its possible effects on the reader ${ }^{5}$ (Botha 2009:486). Briggs (2001) further emphasises that:

[A]t heart, speech act theory concerns itself with the performative nature of language: with the topic of how language 'utterances' are operative and have effects, whether they occur in face-to-face personal conversation or in any communicative action. (p. 3)

Following Briggs' assertion, this article concerns itself with the performative nature of forensic dialogues in Susanna. This article proposes that Susanna is a fertile ground for this kind of exploration. Susanna seems to be a story possibly crafted with the intent to address issues of social injustice within the Babylonian Jewish community, and the reader is called to pay attention to it through this story. With regard to the methodology to be utilised in the analysis, it is beyond the scope of this article to discuss it in detail. Speech act theory is a well-established methodology for literary studies. For the purpose of clarity, the terminology and concepts used in speech act theory are summarised in the work of Botha (2009:487-488). He points out that in any utterance, three acts are performed: the locutionary act (the production of an intelligible and recognisable combination of words), the illocutionary act (an act the speaker performs when making a specific utterance, e.g.,

4. When defining this approach of analysis, Briggs (2001:3) indicates that " $[\mathrm{s}]$ peech-act theory is the name given to a type of inquiry brought into focus by the work of theory is the name given to a type of inquiry brought into focus by the work of
J.L. Austin in his 1955 William James lectures at Harvard, and later published as How to do things with Words' (cf. Tovey 1997:70).

5.This article will use the term 'reader' to refer to an implied reader. The implied reader is the inner-textual (personified construction that systematically discovers what the implied author presents. The implied reader as inner-textual construct knows nothing at the beginning of the narrative, but is indeed constructed as the narrative develops. As the narrative unfolds, the implied reader is informed by everything the narrative has to offer, and the knowledge of the implied reader increases proportionally. Within the framework of the growing knowledge, the increases proportionally. Within the framework of the growing knowledge, the implied reader will have to make sense of every piece of new evidence and integrate it into the existing body of knowledge this reader already has. New information will constantly be considered and interpreted in light of existing information up to that point in the narrative. Stylistic issues, such as creating or easing tensions, redefinin and expanding existing definitions of concepts, inter-relating information and so on will in this way be developed and enriched within the construct of the implied reader (Van der Watt 2009:88). 
stating, warning, requesting, commanding, representing, threatening and so on) and a perlocution or perlocutionary act (the intended effect inherent in an utterance). ${ }^{6}$ This article is limited to only exploring the basic aspects of speech act theory, specifically the study of utterances and their possible effects on the reader.

In order to explore the performative nature of forensic dialogue in Susanna, this article approaches the story in the following way:

- It identifies utterances that include a forensic argument. Not all the utterances can be dealt with in a single study. For the sake of textual space, the article is limited to a selection of occurrences and a demonstration of their performative nature and function.

- The article thereafter discusses the illocutionary force of the identified utterance and how it contributes to the literary brilliance of Susanna. The article also pays attention to the text semantically; the focus here is on the meaning of the passage. On this level of analysis, the contextual meanings of key words in the story also receive attention (see Austin 1975; see also Tovey 1997:70). Briggs (2001:4) adds that more recently there has been a growing literature involving the use of speech act theory in Biblical and Theological Studies. In the arena of pragmatics, speech act theory is a useful tool to enable interpreters to focus on the performative aspects of a language (Botha 2009:486).

- The discussion of the perlocutionary force ${ }^{7}$ or the performative nature of the forensic dialogue (taken from a particular utterance) is discussed in the last instance. In this section, the article focuses on the possible intended effects of the forensic dialogue for the reader.

\section{Analysis of the performative nature of forensic dialogue in Susanna}

The story of Susanna can be divided into four episodes: verses 1-14 (introduction of Joachim and Susanna and their family; Susanna's beauty attracts two elders), verses 15-27 (the elders attempt to seduce Susanna; the elders accuse Susanna), verses 28-46 (the elders testify against Susanna; Susanna is sentenced to death) and verses 46-64 (Daniel rescues Susanna; the elders are sentenced to death). The analysis focuses on the three major parts of the story, that is, verses $15-64$.

\footnotetext{
6.When providing a summary of Austin's assertion on these acts, Briggs (2001:40) also says: "locutionary act is the normal sense of "saying something"; and the term Illocutionary act is the performance of an act in saying something as opposed to performance of an act of saying something and the perlocutionary act is an act performed in such a way that it has consequential effects upon the feelings, thoughts, or actions of the audience, or of the speaker or other person'. See also Tovey (1997:70-71) and Austin (1975) for similar discussion. See also Thiselton (1992:21-298), Ito (2015:141) and Bach and Harnish (1979:42) for similar elaboration.

7.Van der Watt (2010:148) indicates that it is obviously not possible to predict how a reader would respond to any specific text. By reading the text closely, it becomes possible to at least give clear indications of the direction the text encourages the reader to take. The broad ideological thrust and the smaller linguistic features of the text will work together to determine the 'encouragement' of the text. In this case, the article aims to determine how the text tries to involve the reader to make the article aims to
particular decision.
}

\section{The introduction of Susanna and the appointment of elders as judges: Verses 1-14}

This article observes that in the first part of Susanna is where most of the story is being 'set', particularly the forensic arguments or concepts. In Verse 1, Susanna, who will shortly be the accused and the victim of injustice, is introduced. Kanonge (2010:72) points out that the reader learns that she is beautiful, is married and has children. Emphasis is placed on the fact that she is God-fearing. She comes from a godly

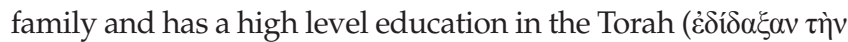

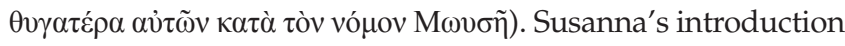
is generally done by the narrator in an informative speech act. With this introduction, the narrator intends to inform the reader of Susanna's qualities. Very critical, in the study of forensics, is the fact that Susanna is a God-fearing woman and has knowledge of the Law of Moses. Therefore, the perlocutionary force of the informative encourages the reader not to associate Susanna with wickedness or lawlessness. The reader can expect Susanna to conduct herself accordingly as the story unfolds.

The second critical forensic aspect found in this first part is the introduction of the two elders in the story. In Verse 5, the text reports the following:

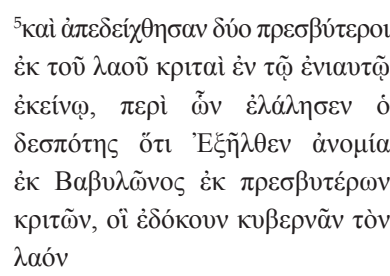

The same year two elders were appointed out of the people to be judges. Concerning them the Lord had said: 'Wickedness came forth from Babylon, from elders who were judges, who were supposed to govern the people'.

The introduction of the two elders is done by the narrator's voice in an informative speech act. This information is important to the reader. The reader notes that the elders are associated with wickedness and sexual perversion, inspired by Babylon (v. 5). Their portrait is incompatible with their function of judges as the protectors of people's rights (Jordaan 2008:121). They are evil and lawless judges. The figure of the judge is portrayed in a negative way. This observation is ironic to the reader and is both shocking and amusing. The elders (judges) who should uphold the law are themselves lawless. The perlocutionary force of the informative invites the reader to be a witness in the story and challenges him or her to pay close attention to the performance of the two elders. It further prepares the reader to expect a dramatic performance of lawlessness and injustice in the execution of their duties. The expectation and anticipation cause tension in the mind of the reader. The first act that undergirds their lawless character is reported in Verse 9:

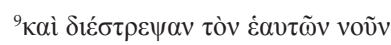

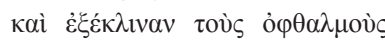

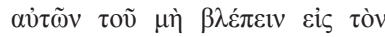

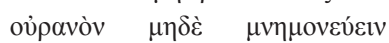

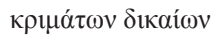

They suppressed their consciences and turned away their eyes from looking to Heaven or remembering their duty to administer justice. 
The narrator's report is an informative speech act. The narrator continues to inform the reader about the conduct of the two elders and how they voluntarily and intentionally break the Law. It seems that their main aim is to have a Jewish community without the Law and thus without God (Kanonge 2010:88). This twofold project is revealed by their designation

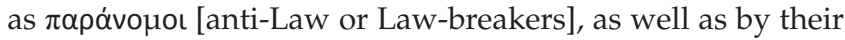
metaphorical gesture of 'turning their eyes against heaven' (Dancy 1972:233). According to Dancy (1972:227), their injustice is seen as a form of practical atheism: 'It involves the rejection of God's will'. The speech act established above helps to resolve the tension in the mind of the reader. The reader, as a witness, is now well oriented to how the lawless judges operate. The degree of their lawlessness is seen in the manner in which they plan the crime or sin that they are about to commit. In this sense, the story prepares the reader to expect the two judges to receive severe punishment, that is, to be cut off from the people of Israel ( $\mathrm{Nm} \mathrm{15:30-31).}$

\section{The actual offense is committed: Verses 15-27}

This section narrates the story of the elders' unsuccessful attempts to seduce Susanna (v. 21). This follows after they first admit their lust for her to each other (v. 14) and to Susanna herself (vv. 20-21). This admission is important for this analysis and deserves some attention. It is recorded in Verse 14 as follows:

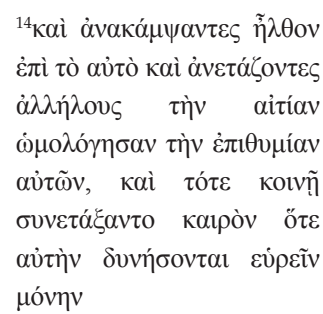

So when they were gone out, they parted the one from the other, and turning back again they came to the same place; and after that they had asked one another the cause, they acknowledged their lust: then together they arranged for a time when they might find her alone.

This utterance is important in that it further provides the reader with conclusive information about the status of the elders in the trial that is about to begin. The utterance is evidently an informative speech act used by the narrator to provide the reader with information. The narrator tells the reader that the elders admitted to each other their lust for Susanna (De Wet 2016:134). Whilst the basic intention of the informative speech act is to inform, its perlocutionary force has the potential to bring further relief to the reader. As discussed in the first part (vv. 1-14), the elders are judges and governors of the people, but they are lawless and are associated with the influence of Babylon (Jordaan 2009:4; Kanonge \& Jordaan 2014:4). The elders, who are supposed to be judges and governors within the community, are said to be lawless and vectors of sexual immorality. Kanonge (2010:7) correctly points out that 'despite their high position, the two elders were highlighted by a prophetic utterance as vectors of sexual perversion in the community'. The speech act advances the intrinsic irony of the story and continues to surprise and amuse the reader. In the minds of the Second Temple Jewish devout, elders, governors and judges are expected to guide the people in the Law of Moses, not otherwise. From a performative point of view, the lawless character of the elders and their admission of lust for Susanna invite the reader to brace himself or herself for the dramatic events in the story. The anticipation of drama sensitises the reader towards the story. The reader is already invited to empathise with Susanna in anticipation of the injustice she is going to experience at the hands of the lawless elders.

\section{The elders attempt to seduce Susanna: Verses 20-21}

The text reports that the elders looked for an opportune time to make their advances on Susanna. Susanna went to the garden with her two maids to bathe because it was a hot day. After she released her two maids and was left alone, the elders seized the opportunity to make their move. The text reports the encounter in verses 20-21 as follows:

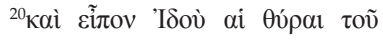
They said, look, the garden

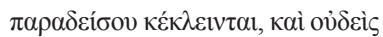

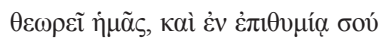

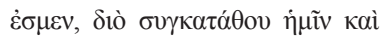

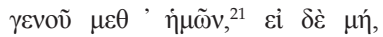

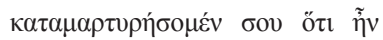

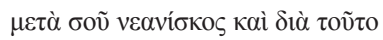

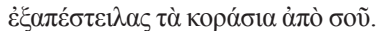 doors are shut, and no one can see us. We are burning with desire for you; so give your consent, and lie with us. ${ }^{21}$ If you refuse, we will testify against you that a young man was with you, and this was why you sent your maids away.

The utterance outlined above is significant because it underlines the depth of the elders' wickedness. In Verse 20, the elders go to Susanna and demand that she agree

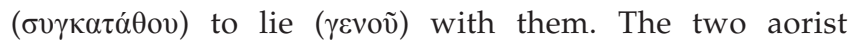
imperatives make this utterance more of a command rather than a request. The utterance here can be categorised as a directive speech act, done with the intention to instruct someone (Susanna) to do what the speakers (elders) are demanding. This directive speech act has perlocutionary force to draw the attention of the reader to the wickedness of the elders and to how they abuse their power. Their duty should be to instruct people in doing right and to administer justice to the people, but here they instruct and use power to do wrong. The directive speech act further confirms the lawless character of the elders. In this way the reader is motivated to continue reading the text to see how the drama unfolds.

In Verse 21, the elders tell Susanna that if ( $\varepsilon \grave{i} \delta \grave{\varepsilon} \mu \eta \dot{)}$ she refuses, they will testify against her. By saying this, the elders plan to give a false testimony against Susanna. This intention is a direct and an intentional disregard of Exodus $20: 16$. The utterance sounds like a threat based on the possibility that she would reject their command to sleep with her. Therefore, the utterance in Verse 21 can be classified as a disputive speech act, done with the intention to strengthen their command that Susanna should concede to their demand. The utterance has the power to further invite the reader to marvel, with disappointment, at the determination of the elders to accomplish their lawless goals to engage in sexual immorality. 


\section{The elders accuse Susanna: Verse 27}

When the elders demand to have sexual intercourse with her, Susanna chooses not to go along with their demand. Her objection is recorded as follows:

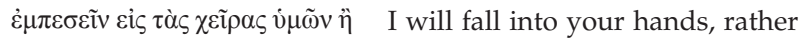

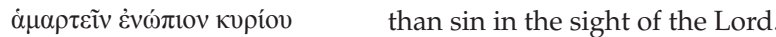

The utterance outlined here underlines Susanna's determination not to commit sin with the elders as opposed to their insistence on wickedness. This utterance should be understood in light of Verse 1, where Susanna is introduced

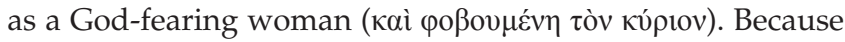
she fears God, she will not commit sin. The speech act involved here is a commissive. According to Botha (2009:488), a commissive 'is an illocutionary act in which the speaker is committing to something in future. It is achieved by vowing or promising or swearing and so on'. The observation here is that Susanna vows not to commit sin by sleeping with the two elders. Her objection emphasises her commitment to Jewish religious values as guided by the Law of Moses (Ex 20:14). Susanna is committed to obedience to the Law and does not succumb to the wicked demand of the elders.

The perlocutionary force of the commissive speech act established above has the potential to encourage the reader to emulate Susanna's fear of God and her determination and commitment to the Law. The commissive speech functions, on the one hand, to evoke the reader's tenacity to obey the Law of Moses. On the other hand, it encourages the reader to disassociate himself or herself from wickedness and Babylonian influences, the trap into which the elders have fallen. The narrator reports that Susanna cries out with a loud voice in her effort to escape from the elders. The people hear her cry and rush to the garden. When the people arrive in the garden, the elders report what has transpired. The text records it in Verse 27:

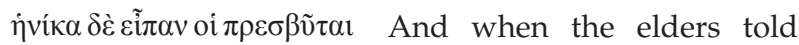

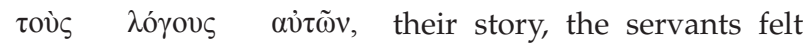

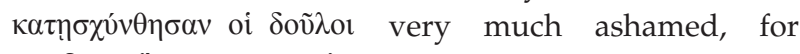

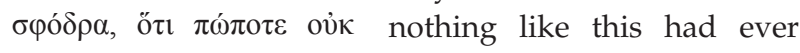

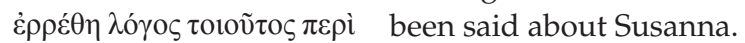

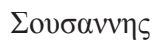

The utterance is reported by the narrator. The elders are not given a textual space to speak for themselves. The utterance is clearly an informative speech act, done with the intention to empower the reader with information about how the elders defended themselves. The narrator reports that the elders told their story and that the servants were very much ashamed. Their shame is directed at Susanna, because nothing like what they just heard about her (as the elders reported) had ever been said about her. It is not clear or explicit in Verse 27 what exactly the elders say about her, but it is evident that they accuse Susanna of some wrongdoing, hence the servants' disappointment. With regard to the shame and disappointment, it can be argued that the reader is spared from this feeling towards Susanna because the reader knows the truth. The reader knows that Susanna is a
God-fearing woman and will not do whatever the elders have reported. At this point, one can argue that the text (the informative speech) is performative in that it increases the anxiety of the reader. The reader is encouraged to continue reading in search of information on what exactly the elders said about Susanna. Therefore, the text invites the reader to stay closer to the narrator in order to get this information.

With regard to the probable accusation levelled against Susanna by the elders, it can be indicated that the perlocutionary force of the informative is strong enough to invite the reader to sympathise with her and consequently feel innocently accused of wrongdoing with her. Because the reader not only identifies with Susanna but also seeks to emulate her, he or she also participates in the pretrial story as an accused together with Susanna.

\section{The elders testify against Susanna: Trial 1 (vv. 28-46)}

The actual trial in the story is reported in verses 28-64. This article divides the trial story into two parts: the first trial is narrated in verses $28-46$ (the elders testify against Susanna) and the second trial is found in verses 47-64 (Daniel rescues Susanna). The first trial begins with the narrator's voice reporting the commencement of the trial against Susanna in the house of her husband Joachim (v. 28). According to Jordaan and Chang (2018:5), the court exists wherever the judges are. They further point out that in the text, the court was held in Joachim's house because 'these men (the judges) were frequently at Joachim's house, and all who had a case to be tried came to them there' (v. 6). It is reported that people gathered to come and hear or participate in the trial (see also Jordaan 2009:4). The narration on the presence of the elders is central here.

The narrator reports it as follows:

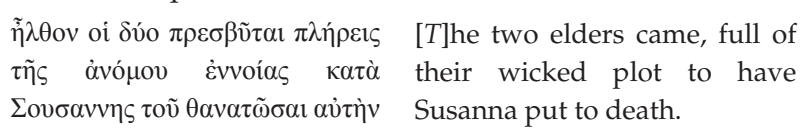

The above utterance of the commencement of the trial is an informative speech act, done with the intention to inform the reader about the characters (people), place and time of the trial in the story. This speech act reveals that the two elders attend the trial as wicked accusers of Susanna (see v. 34), false witnesses (of their own) and corrupt judges in the trial, whilst Susanna is an innocent accused in the trial and the charge or allegation is sexual immorality (as can be deduced from the previous section, vv. 15-27). As indicated earlier, the role of the reader, whom the story invites to emulate Susanna, is that of a witness and also an accused by virtue of their identification and sympathy towards Susanna.

It can be argued that the perlocutionary force of the informative speech act in Verse 28 has the power to persuade the reader (real or implied), who is both a witness and an accused, to continue empathising with Susanna more than with the two elders, particularly when one considers the narrator's aside 
(note) that 'the two elders came, full of their wicked plot to have Susanna put to death'. The reader, who is from the Jewish faith, is implicitly invited to empathise with Susanna in the trial and hope to be vindicated together with her. As such the reader must brace himself or herself for a tough trial for Susanna because it has been reported that the elders came full of their wicked plot to have Susanna killed. This aside underscores the elders' determination to advance wickedness in the community. Therefore, the informative speech act has the power to invite the reader to support Susanna in her quest to defend the Jewish religious values.

After the elders laid their hands ${ }^{8}$ on Susanna, the narrator continues to report that the following:

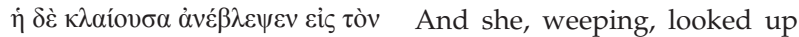

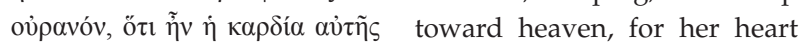

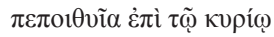
trusted in the Lord.

Once again, the speech act involved is an informative. The intention of the utterance is to inform or to empower the reader with the information regarding Susanna's response to the actions and accusation by the two elders. Susanna's act of weeping whilst looking towards heaven and the narrator's aside that 'her heart trusted in the Lord' have a disputive tone in them. Susanna cannot defend herself, but can only trust in the Lord for vindication. Therefore, the informative speech act has the power to challenge the reader to re-evaluate his or her faith and encourage him or her to trust in the Lord also, particularly in the difficult times of the diaspora. It is striking that contrary to the report that the elders came to the trial with a wicked plot, Susanna is reported as coming to the trial trusting in the Lord for a fair judgement and vindication. The reader is encouraged not to emulate the wicked elders (and corrupt judges) in the story, but rather Susanna.

Susanna's weeping is followed by the narration of the false testimony by the two elders (vv. 36-41a). The use of direct speech in reporting the testimony makes the story vivid and dramatic. The narrator does not report on their behalf, but rather provides the textual space for the wicked elders to present their testimony, upon which they accuse Susanna of adultery. The direct speech of the testimony recorded in verses $37-40$ has two illocutionary acts in it. Firstly, it can be categorised as an illocutionary act belonging to the category of assertives. ${ }^{9}$ In making the speech, the two elders explain and affirm how they witnessed the adulterous act unfolding (although it is a lie). Secondly, the direct speech can also be categorised as a disputive speech act. In making the speech, the two elders argue their case and confirm that Susanna committed adultery with a certain young man. The disputive speech also has a confirmative tone in it, particularly Verse $41 \mathrm{a}$, when they say ' $\tau \alpha \tilde{\tau} \tau \alpha \mu \alpha \rho \tau \nu \rho o \tilde{\mu} \mu \varepsilon{ }^{\prime}$ ['these things do we testify'].

8.As Collins (quoted by Clanton 2006:74) states, 'the ritual of placing hands on the head occurs in three contexts in the Bible: in the preparation of animals for sacrifice headicus 8:14,18,22. Exodus 29:10,16,19); in the ritual of the scaper (Levitice (Leviticus $8: 14,18,22 ;$ i $x$ dus $29: 10,16,19$; i the ritual of the scapegoat (Leviticus $16: 21-22)$; and in the condemnation of blasphemers (Leviticus 24:14)'. The ritual is
meant to punish Susanna's alleged adultery.

9.The schema of assertives by Bach and Harnish (1979:42) is as follows: Assertives affirm, allege, assert, aver, avow, claim, declare, deny and so on (see also Ito 2015:264).
The perlocutionary force of these speech acts means that people should take note of the testimony and continue with the trial. The reader should also take note of the testimony and continue to listen to further testimonies, particularly Susanna's response.

However, it must be pointed out that both speech acts established above are disappointing to the reader. The reader already has some knowledge about the two elders, namely, that they are full of wickedness and they plot to have Susanna killed for wrongs that she did not commit (v. 28). Whilst the two elders insist that their testimony is true, the reader knows that it is not. The elders can fool the attendees of the trial but not the reader. In performative terms, this part of the trial is presented in such a way that the wickedness of the elders is exposed to the reader and they cannot be emulated. Although the elders still pretend to be truthful, their act is both amusing and disappointing to the reader because he or she knows the truth. The reader is persuaded to distance himself or herself from the wicked elders and to sympathise more with Susanna. In fact, the reader is, on the one hand, invited to lay a charge of intentionally giving false testimony (Ex 20:17) against the elders. However, it is noted that they unfortunately cannot, which is the tragedy of the story. On the other hand, the reader is encouraged to continue empathising with Susanna and be a witness of her innocence.

Regardless of her innocence, Susanna is sentenced to death. In response to the false testimony by the elders, Susanna cries with a loud voice to the Lord for help. Her prayer is recorded in verses $42-43$ :

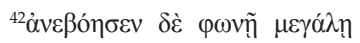

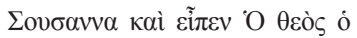

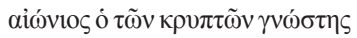

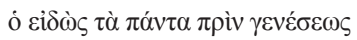

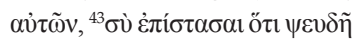

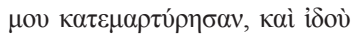

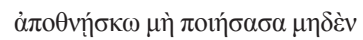

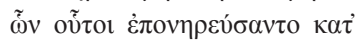

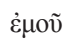
Then Susanna cried out with a loud voice, and said, $\mathrm{O}$ eternal God, you know what is secret and are aware of all things before they come to be; ${ }^{43}$ you know that these men have given false evidence against me. And now I am to die, though I have done none of the wicked things that they have charged against me!

Susanna's prayer reveals her unwavering faith in and knowledge of God. Susanna's prayer reveals that she knows that God is the eternal God; he (the reader also) knows what is done in secret (because God knows and sees what is done in secret, he may well be Susanna's witness, just like the reader). God is aware of all things before they come to be; he knows that these men have given false evidence against her and that she is innocent.

The utterance can be categorised as an illocutionary act belonging to both the assertive and disputive speech acts. In uttering the prayer, she on the one hand asserts her conviction and faith in God, and on the other hand she disputes the judgement passed against her. She challenges it as a judgement based on false testimony $(\psi \varepsilon v \delta \tilde{\eta} \mu \mathrm{ov}$ $\kappa \alpha \tau \varepsilon \mu \alpha \rho \tau u ́ \rho \eta \sigma \alpha v)$. She reveals that she is to die for a wrong she did not commit. The perlocutionary force of these two speech 
acts invites the people to take note of Susanna's prayer and its content (the claims she is making and the false evidence she is disputing). At this point, the text grants the reader an opportunity to take note of the prayer and to begin to weigh the evidence and testimony of the elders against the prayer of Susanna.

It is observed that the procedure and the unfolding of the trial create tension within the reader. The reader is at a point where he or she does not know what will happen next. Susanna is about to be put to death for the wrong she did not commit, whilst the reader can only stand and watch, even though he or she knows the truth.

The narrator's report in verses $44-46$ comes as a huge relief for the reader. The text reports it as follows:

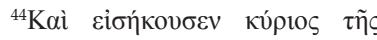
${ }^{44}$ The Lord heard her cry. ${ }^{45}$ Just $\varphi \omega v \tilde{\eta} \varsigma \alpha \hat{\tau} \tilde{\eta} \varsigma .{ }^{45} \kappa \alpha i ̀ ~ \alpha ่ \pi \alpha \gamma o \mu \varepsilon \dot{v} \eta \varsigma_{\varsigma}$

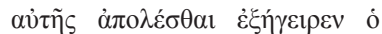

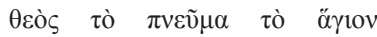

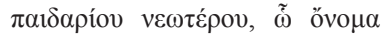

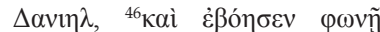

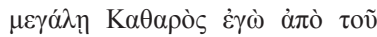

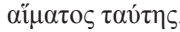 as she was being led off to execution, God stirred up the holy spirit of a young lad named Daniel, ${ }^{46}$ and he shouted with a loud voice, 'I want no part in shedding this woman's blood!'.

The first trial concludes with the voice of the narrator reporting God's intervention in the trial. Two utterances are critical here. The first is the utterance in Verse 44, which states

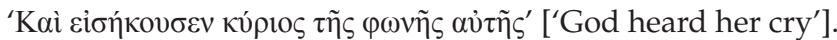

As a way of answering Susanna's prayer, God stirs up the Holy Spirit in the young man called Daniel. The utterance is an informative speech act, done with the intention to inform the reader about God's intervention in the trial. The reader should take note of this dramatic and miraculous intervention. However, this informative speech does more than just give information to the reader. It brings resolution to the tension in the mind of the reader, who has just experienced an unfair judgement against Susanna. God's intervention also strengthens the faith of the reader (who is of the Jewish faith) and encourages him or her to continue trusting in God.

Secondly, the utterance in verses 45-46 further narrates God's intervention through the young man called Daniel. Daniel is introduced as a character inspired by God to intervene in the trial so that a fair judgement can be reached. In protest against the judgement that Susanna be put to death, Daniel shouts and says to the people (v. 46):

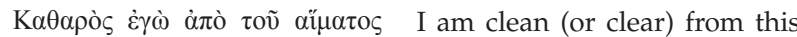

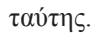
woman's blood!

The introduction and the role that Daniel plays in the trial are interesting. He is introduced as an accuser of the wicked elders (corrupt judges), the advocate of Susanna and a judge in the trial. It can be argued that because Daniel represents God's interests (as the implied righteous judge) in the story, it is safe to see his role as a judge in the trial. Daniel as the accuser and the advocate of Susanna is the one who tests the stories of the elders, who does cross-examination, who speaks on behalf of Susanna, as will be discussed a little later.
The fact that he does not agree with the judgement of the elders shows that he accuses them of wrongdoing. His claim and declaration in Verse 46 qualifies him to assume all three roles in the trial.

Therefore, the utterance can be categorised as both an assertive and a disputive speech act. By asserting and declaring that he wants nothing to do with Susanna's execution, Daniel is disputing and challenging the outcome of the trial. The perlocutionary force is such that the people should take note of Daniel's interjection. The reader is also invited to take note of Daniel's claim and give him a chance to contribute to the trial. This development should be exciting to the reader. It signals hope and the prospect of finally getting a fair judgement for Susanna. It must further be indicated that the excitement of the reader is based on the fact that he or she knows that Susanna is innocent.

\section{Daniel rescues Susanna: Trial 2 (vv. 47-64)}

The second trial proceedings convene after the people heed Daniel's objection to the outcome of the first trial. As already alluded to, Daniel assumes his role as the accuser of the wicked elders (for having made a judgement based on false testimonies), the advocate of Susanna and a judge. Susanna is a victim of injustice perpetuated by the elders. After Daniel shouts, all the people come to him to seek clarity on what he says in Verse 47, saying:

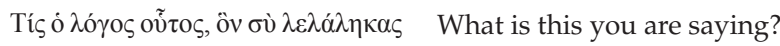

The people approach Daniel, seeking to understand what he means with his utterance in Verse 47. Their utterance is a question speech act, done with the intention to seek clarity on Daniel's claim or objection. The reader should take note of the question and await Daniel's answer to it. It must be indicated that the reader's interest in the second trial is less on Susanna's innocence (because the reader knows that Susanna is innocent) and more on the wicked elders' guilt. The reader is itching to see if the elders will get away with their wicked plot. Daniel admonishes the people for their foolishness for allowing the elders to condemn Susanna, the daughter of Israel, without proper examination and without learning the facts. Therefore, Daniel calls all the people back to the court (the place of judgement), as reported in Verse 49:

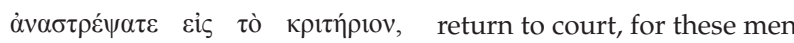

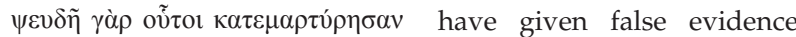
$\alpha \cup ๋ \tau \tilde{\varsigma}$ against her.

The utterance here is a directive speech act, with a disputive tone in it. The intention of the speech act is to call people back to

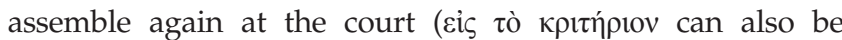
translated as 'a place of judgement'). Daniel pleads with the people to come back so that he can expose the false evidence given by the elders. By doing this, Daniel is disputing the judgement handed down to Susanna. Daniel protests because the judgement of the first trial was based on false evidence by the elders. The perlocutionary force of the directive speech invites the reader, as a witness, to consider going back to 
court together with the rest of the people. This invitation is exciting and gives hope to the reader. In fact, it should be asserted that the reader, who is from the Jewish faith, cannot turn down such an invitation or command, because he or she knows about Susanna's innocence and the elders' wickedness. The second trial formally congregates as reported in Verse 50. Daniel takes a stand and begins to examine the elders. Some elders show some appreciation for Daniel (v. 50). They invite him to sit amongst them, acknowledging that God has given him the standing of an elder. In Verse 51, the text reports the commencement of the trial as follows:

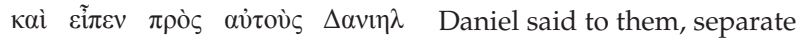
$\Delta 1 \alpha \chi \omega \rho i \sigma \alpha \tau \varepsilon \alpha \dot{v} \tau o \dot{\varsigma} \varsigma \dot{\alpha} \pi^{\prime} \dot{\alpha} \lambda \lambda \dot{\eta} \lambda \omega v$ them far from each other, and

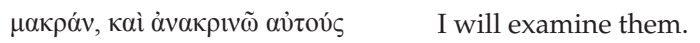

In this utterance, Daniel requests that the two elders be separated as he commences with the cross-examination. It must be remembered that the main charge against the elders in the second trial is Daniel's claim that they gave false testimony against Susanna and therefore have misled the people and perpetuated injustice in the covenant community. The utterance can be categorised as a directive speech act (soft command). In making this speech act, Daniel's intention is to lay down the procedure of the trial. The speech act calls for people to do as Daniel commands. The speech act also heightens the tension in the mind of the reader. However, it is exciting for the reader to witness how the trial continues. The performative nature of this speech act is that the reader is inspired to continue reading the story to find out how Daniel will expose the two wicked elders. In the context of the diaspora, the reader is reminded that the Israelites are expected to strive for fairness and truth and expose wickedness and unfair judgements in their court proceedings. It can also be argued that amongst other themes, Susanna can thus be read as a document that seeks to denounce social injustice amongst the people of the covenant community. The reader is encouraged to emulate the faith of Susanna and the courage of Daniel in defending the values of the Jewish faith. Daniel takes a stand and begins with the cross-examination (v. 52) of the two elders.

He eventually exposes their wickedness and their false testimony against Susanna (vv. 52-59). The utterances used in the process of examination are a series of question-response speech acts, done with the intention to establish facts on the testimony of the elders. The perlocutionary force of the question-response speech acts has the power to amuse the reader. The manner in which Daniel deals with the elders involves wisdom and tenacity (see also Du Bruyn 2014:6; Widder 2014:1121). The dramatic way in which Daniel handles the trial has the power to sensitise the reader towards the story. The reader is encouraged and strongly enticed to join both Susanna and Daniel in their pursuit to defend the Jewish religious values. Daniel eventually establishes the facts and pronounces judgement upon the elders, saying:

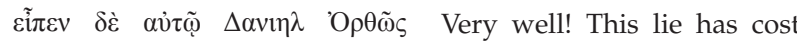

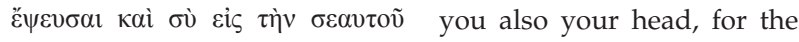

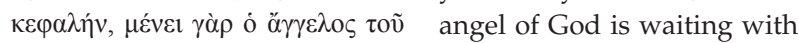

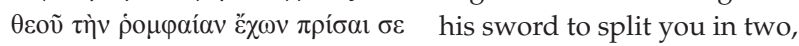

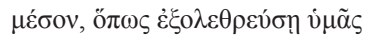

The speech act involved here is a declarative, in that by uttering it Daniel passes the final sentence on the two elders. The people are therefore invited to accept this sentence as genuine and fair. In performative terms, the declarative in this instance has the power to invite the reader to assume his or her role as a judge in the trial also. The story invites the reader to judge the two elders for their mischievous acts against Susanna. The declarative further brings the reversal of roles in the story; the accusers become the accused, the judges are themselves judged and put to death. The article further notes that this is the irony of the story of Susanna. The story concludes with the narrator's report of the joy and praises of the people towards God for sparing innocent blood (Susanna). The two wicked elders are put to death, following the Law of Moses (v. 62). The execution of the two elders (v. 62) is recounted as a proof of Susanna's innocence (Kanonge 2010:8862).

The report in verses 60-64 should encourage the reader to continue trusting in God and denouncing injustice. By means of this dramatic forensic dialogue, the story successfully advocates for the observance of Jewish religious values (anti-sexual immorality and anti-social injustice) in the diaspora. This observation is similar to that of Harrington (1999:114) when he says: '[ $t$ ]he story is designed to deal with wickedness, especially "sexual perversion", in the Babylonian Jewish community' (see also Moore 1977:91). It can also be added that the story of Susanna is indeed a story of the restoration of justice as opposed to the assertion in Verse 57 within the Jewish community of the Second Temple period.

\section{Summary of findings}

The goal of this article was to investigate the performative nature of forensic dialogues in the story of Susanna from a speech act interpretive angle. The overarching pursuit of the article was to demonstrate how forensic texts invite the reader to participate in the story. The article focused on the whole story of Susanna, that is, verses 1-64. In order to establish the performative function of forensic dialogues in Susanna, the article analysed unit utterances presented by the narrator as carefully planned by the author. The findings can be summarised in the following way.

\section{The introduction of Susanna and the appointment of elders as judges: Verses 1-14}

In the introduction of Susanna and the elders, the reader notes that the elders are leaders who are associated with wickedness and sexual perversion. Their portrayal is incompatible with their function of judges as the protectors of people's rights. This observation was noted as ironic to the reader and is both shocking and amusing. The elders (judges) who are supposed to uphold the law are themselves lawless. 


\section{Accusation against Susanna}

This article established that with regard to the accusation levelled against Susanna by the two wicked elders, the perlocutionary force of the informative speech act used in Verse 27 is strong enough to make the reader (who identifies himself or herself with the religious values that Susanna stands for) sympathise with her. He or she consequently shares in Susanna's pleas of wrongdoing. The reader subsequently participates as an accused in the pretrial story.

\section{The elders testify against Susanna: Trial 1 (vv. 28-46)}

The perlocutionary force of the informative speech act established in Verse 28 has the power to persuade the reader to continue sympathising with Susanna more than the two elders, particularly when considering the narrator's aside (note) that 'the two elders came, full of their wicked plot to have Susanna put to death'. However, the speech acts are both amusing and disappointing to the reader. As the two elders pretend to be true before the people, the reader knows that they are full of wickedness and are trying to plot to have Susanna killed for wrongs that she did not commit (v. 28). The first trial concludes with Daniel's voice calling the people back to court. Daniel disputes and challenges the outcome of the first trial. The reader is invited also to dispute the outcome and waits for Daniel to contribute to the trial, hoping for another outcome in favour of Susanna.

\section{Daniel rescues Susanna: Trial 2 (vv. 47-64)}

Daniel finally exposes the wickedness of the two elders. Through dramatic forensic dialogue, the story successfully advocates for the values of the Jewish faith in the diaspora. The reader is encouraged to emulate Susanna and Daniel in defence of the Jewish faith in the Second Temple period. Daniel's and Susanna's victory is seen as the victory of Judaism over wickedness. The story concludes with a reversal of roles as the accusers become the accused - the judges are themselves judged and put to death. The performative nature of forensic dialogues as revealed by the analysis in this article gives the reader an opportunity to participate in this role as the story unfolds.

\section{Conclusion}

In conclusion, the article observes that, whilst Susanna and other characters function as performative role-players in the trial proceedings, the trial is in fact against Judaism. As Kanonge (2010:183) says, '[t]he elders suffer execution and the Jewish community escapes wickedness'. Susanna's victory is the victory of the Jewish faith over wickedness and social injustice. In light of Verse 57, it seems that the story projects itself as a critique against the judiciary of ancient Judaism, particularly in the Babylonian diaspora. Susanna emerges as a voice that represents the weak and the voiceless in the community. Unless the reader chooses to ignore the textual evidence, the study of forensic dynamics in Susanna invites him or her to emulate the faith and courage of Susanna and Daniel. The reader is also encouraged to condemn wickedness and corrupt judgements. Furthermore, the reader is encouraged to be the promoter and advocate of social justice in their own contexts, including the South African context. In the contemporary world or society where social justice is at the forefront of politics, Susanna can be read as a guide towards fighting social injustice.

\section{Acknowledgements}

This article was finalised after having been presented at the 33rd Biennial Conference of the Classical Association of South Africa at Stellenbosch University on 07-10 November 2019. All the comments and suggestions from the various scholars present were taken into consideration in the finalisation of this article.

\section{Competing interests}

The author declares that he has no financial or personal relationships that may have inappropriately influenced him in writing this research article.

\section{Ethical considerations}

This article followed all ethical standards for research without direct contact with human or animal subjects.

\section{Author's contributions}

R.S.H. is the sole author of this research article.

\section{Funding information}

This research received no specific grant from any funding agency in the public, commercial or not-for-profit sectors.

\section{Data availability statement}

Data sharing is not applicable to this article as no new data were created or analysed in this study.

\section{Disclaimer}

The views and opinions expressed in this article are those of the author and do not necessarily reflect the official policy or position of any affiliated agency of the author.

\section{References}

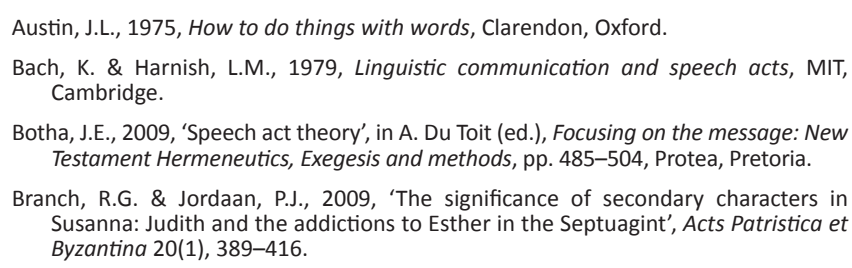


Briggs, R.S., 2001, Words in action: Speech act theory and biblical interpretation, T\&T Clark, Edinburgh.

Charles, R.H., (1913) 2004, 'The Apocrypha and Pseudepigrapha of the Old Testament', in R.H. Charles (ed.), vol. 1, Apocrypha, The Apocryphal Press, Berkeley, CA.

Coetzer, E., 2009, 'Performing Susanna: Speech acts and other performative elements in Susanna', in J. Cook (ed.), Septuagint and reception: Essays prepared for the association for the study the Septuagint in South Africa, pp. 347-360, North-West University, Potchefstroom.

Collins, J.J., 1993, Daniel, Hermeneia, F.M. Cross (ed.), Fortress Press, Minneapolis, $\mathrm{MN}$

Dancy, J.C., 1972, The shorter books of the Apocrypha: TOBIT, Judith, Rest of Esther, Baruch, Letter of Jeremy and Additions to Daniel and Prayer of Manasseh, Cambridge University Press, Cambridge.

De Bruyn, J.J., 2014, 'A clash of gods: Conceptualising Space in Daniel 1', HTS Theological Studies 70(3), 1-6. https://doi.org/10.4102/hts.v70i3.1956

De Bruyn, J.J., 2015, 'Susanna: Framing the minds and views of people', Journal of Semitics 24(2), 594-612. https://doi.org/10.25159/1013-8471/3470

De Bruyn, J.J., 2016, 'Susanna-framing the minds and views of people in Daniel', in P.J. Jordaan \& N.P.L. Allen (eds.), Construction, coherence and connotations: Studies on the Septuagint, Apocryphal and Cognate Literature, pp. 221-232, De Gruyter, Berlin.

De Wet, C.L., 2009, 'The reception of Susanna Narrative (Dan. XIII)', in J. Cook (ed.) Septuagint and reception: Essays prepared for the Association for the Study of the Septuagint in South Africa, Vetus Testamentum Supplements, pp. 229-244, Brill, Leiden.

De Wet, C.L., 2016, 'Susanna's body', Biblische Notizen 168(1), 129-144.

Harrington, D.J., 1999, Invitation to the Apocrypha, Eerdmans Publishing Company, Grand Rapids, MI.

Ito, H., 2015, 'A Speech Act Reading of John 9', Acta Theologica 21(2015), 91-448. https://doi.org/10.4314/actat.v21i1S.146099

Jordaan, P.J., 2008a, 'Daniel as a weapon for attack and defense through the ages', Ekklesiastikos Pharos 90(19), 45-53.
Jordaan, P.J., 2008b, 'Reading Susanna as therapeutic narrative', Journal for Semitics $17(1), 114-128$.

Jordaan, P.J., 2009, 'The pendulum is never static: Jesus Sira to Jesus Christ on women in the light of Judith, Susanna and LXX Esther', HTS Teologiese Studies/Theological Studies 65(1), 180-183. https://doi.org/10.4102/hts.v65i1.167

Jordaan, P.J. \& Chang, C., 2018, 'Penetration of private places in Theodotian Susanna', HTS Teologiese Studies/Theological Studies 74(3), a5004. https://doi.org/10.4102/ hts.v74i3.5004

Kanonge, D.M., 2009, 'Reading narratives in the Septuagint: A discourse on method', in J. Cook (ed.), Septuagint and reception, Vetus Testamentum Supplements, pp. 361-381, Leiden, Brill.

Kanonge, D.M., 2010, 'The emergence of women in the LXX Apocrypha', PhD thesis, Faculty of Theology, North-West University.

Kanonge, D.M. \& Jordaan, P.J, 2014, 'On the role of Susanna in Susanna: A Greimassian Contribution', HTS Teologiese Studies/Theological Studies 70(3), Art. \#1971, 7 pages. https://doi.org/10.4102/hts.v70i3.1971

Moore, C.A., 1977, Daniel, Esther and Jeremiah: The additions, Doubleday \& Company, Garden City, NY.

Nolte, S.P. \& Jordaan, P.J., 2010, 'Susanna: A story of dangerous spaces', Journal for Semitics 19(2), 507-527.

Thiselton, A.C., 1992, New horizons in Hermeneutics: The theory and practice of transforming Biblical reading, Harper Collins, London.

Tovey, D., 1997, Narrative Art and Act in the Fourth Gospel, Sheffield Academic Press, Sheffield.

Van der Watt, J.G., 2010, 'Ethics through the power of language: Some explorations in the Gospel according to John: Moral language in the New Testament', Mohr siebeck 2(296), 139-169.

Widder, W.L., 2014, 'The court stories of Joseph (Gen 41) and Daniel (Dan 2) in Canonical context: A theological paradigm for God's work among the nations', Old Testament Essays 27(3), 1112-1128.

Ziegler, J., 1999, Susanna Daniel Bel et Draco, Vandenhoeck \& Ruprecht, Göttingen. 